\title{
The impact of the emission trading scheme on the european steel industry and the future trends for technologies for obtaining primary iron
}

\author{
Jean Philippe Santos Gherardi de Alencar ${ }^{1 *}$ (1) \\ Wander Luiz Vasconcelos ${ }^{2}$ \\ Valdirene Gonzaga de Resende ${ }^{1}$
}

\begin{abstract}
Climate change is often subject of discussions around the world that implies in several initiatives that support the reduction of greenhouse gases (GHG). Currently, countries that signed the Paris Agreement in 2015 have plans to restrict GHG emissions based on the NDC (Nationally Determined Contributions) established. These reductions are expected to come also from industries, including the steel one. Some countries and regions are highlighted for having more developed policies than the rest of the world, such as Europe, which since 2005 has been implementing an Emission Trading Scheme (ETS). In this context, the European steel industry has been facing challenges which impose a need for disruptive technology innovation. This work presents four different European steel mills from different countries. A variety of finished products were analyzed, and it was found that in all four cases there is a deficit between the verified GHG emissions and the licenses granted for emission. The specific emissions per ton of steel and energy efficiency of each plant play an important role in justifying these differences in $\mathrm{CO}_{2}$ balance among the plants. Therefore, there are multiple initiatives in progress involving steel producers in Europe that encourage the use of new technologies and modified routes to reduce and mitigate the volume of emissions in the steel production chain. The success of these initiatives from a technical and an economic point of view is the path to sustainability, competitiveness and value generation for the future industry.
\end{abstract}

Keywords: Greenhouse gases; Emissions; Ironmaking; Steelmaking.

\section{Introduction}

Climate change has become one of the most important issues in global politics. The Kyoto protocol, introduced in 1997, was the first international agreement to reduce GHG (Greenhouse Gases) [1]. The Paris agreement, signed in 2015 and valid since November 2016, aimed to limit climate change in this century to below $2{ }^{\circ} \mathrm{C}$ above pre-industrial levels and to pursue efforts to limit the temperature increase even further to $1.5^{\circ} \mathrm{C}$ [2]. This agreement was ratified by 179 countries, which are in different stages of implementing/ developing their policies [3]. This global consensus on the need to take action against climate change implies on the acceleration of policies and regulations that inevitably bring impacts to the industrial competitiveness of all countries and their respective economies [4].

In this context, the European Union (28 countries), Norway, Iceland and Liechtenstein have been committed to a regulated carbon market, the ETS (Emissions Trading Scheme), which aims to promote the reduction of GHG by 95\% until 2050 (compared to 1990 emission levels) [5]. According to the World Steel Association (2018), the global steel production accounts for approximately 7 to $9 \%$ of direct $\mathrm{CO}_{2}$ emissions [6] and, as a result, it is irrefutable that discussions about GHG reduction policies have a direct and deep impact on the steelmaking chain.

Thus, this work shows an approach of how GHG reduction policies takes place and how they have impacted steel industry and its competitiveness.

\subsection{GHG reduction policies around the world}

Each of the signatory countries to the Paris agreement is at a different level of policies implementation that aim to reduce the number of GHG emissions. There are cases ranging from prohibiting emissions from certain sources, imposing taxes or fines for emissions beyond what is desirable and what has been most widely accepted in capitalist economies is the creation of emissions trading schemes. In this context, it is relevant to highlight the role of the ICAP (International Carbon Action Partnership), which is an international forum for governments and public authorities to exchange best practices, data and information regarding their carbon regulation systems and promote the discussions about a global credit carbon market [7].

${ }^{\prime}$ Vale S.A., Nova Lima, MG Brasil.

${ }^{2}$ Departamento de Engenharia Metalúrgica e de Materiais, Universidade Federal de Minas Gerais - UFMG, Belo Horizonte, MG, Brasil.

*Corresponding author: jeanpga@gmail.com 
Nowadays, Asia-Pacific (APAC) is the region that has the largest share of total carbon emissions regulated by implemented ETS systems, closely followed by Europe and less by the American continent. ICAP monitors these ETS systems, indexes and consolidates them on its web page. Through the quotes from January 2020, it is noted that while in some places like Korea and Europe each 1 ton of $\mathrm{CO} 2$ is quoted close to 30 USD, in other places like pilots' markets in China the quotation is around to 5 USD per ton [7].

Regardless the approach that each country has been following, the Paris agreement through the NDC established long-term goals that each signatory should honor in order to contribute to mitigating the impacts of climate changes. It is observed that countries have stipulated levels of reduction that are quite different from each other.

The reduction proposed by Europe is quite audacious while China's reduction may not be proportionately high, but it will have a significant impact on the absolute number of tons of $\mathrm{CO}_{2}$. On the other side, Brazil has assumed a goal of reducing emissions by $37 \%$ by 2025 , based on the 2005 figures [8].

\subsection{Context and current stage of European ETS}

The European ETS has been implemented by steps. In 2005, it was initially launched as a pilot plan and now is in its third stage. The fourth stage begins in 2021, with a period extending from 2021 to 2030 . The total regulated volume covers approximately $45 \%$ of all emissions in Europe. Sectors such as steel, thermoelectric, refineries, cement, refractories, glass, bricks, ceramics, paper and cellulose, electricity generators, combustion plants and airlines are included, accounting for more than 11,000 industrial installations [9].

The EU ETS limits overall GHG emissions of all participants in the system, in any given year, to a specific amount in tons of $\mathrm{CO}_{2}$ equivalent $\left(\mathrm{tCO}_{2} \mathrm{e}\right) \cdot \mathrm{CO}_{2 \mathrm{e}}$ is a metric measure used to put the emissions from various GHG on similar basis according to their global-warming potential (GWP). The free allocations are defined each year to the exact the same number as the total GHG limit set for the year and it is distributed through auctions to participants in the system, who can also freely trade them amongst themselves. By April $30^{\text {th }}$ of each year, participants must provide regulators with one allowance to cover each single ton of $\mathrm{CO}_{2 \mathrm{e}}$ they emitted in the previous year. Non-compliance results in a heavy fine of EUR $100 / \mathrm{tCO}_{2 \mathrm{e}}$ for each ton of emissions without the corresponding allowance [5]. Since the third stage of ETS Europe, emission allowances were distributed to Member States using a benchmark formula applied at the installation level. This calculation considers five components: reference value (benchmark), historical activity level, exchange factor, carbon leakage and a correction factor.

Each of these factors refers to a specific point of analysis. The benchmark value is based on the average emission levels of $10 \%$ of the most efficient installations in the sector. The level of historical activity indicates the most common value of production for a given reactor. The exchange factor is determined by taking into account whether the process fuel or energy is convertible to produce heat or mechanical energy to produce an equivalent product. Any sector that faces a significant risk of carbon leakage from exposure to non-EU competition due to price on $\mathrm{CO}_{2}$, will receive up to $100 \%$ in this factor. Finally, the correction factor is an instrument that ensures that the total allocation remains less than the maximum limit quantity.

Based on these surveys of installed capacities, free allocations and verified emission analyzes, it was possible to carry out a diagnosis of Europe's steel mills regarding their GHG balance.

\section{Methodology}

In order to provide a better understanding of the data collected, the work was divided into four different topics: (i) GHG policies around the world; (ii) ETS context and current stage; (iii) Case study of some steel mills in Europe; and (iv) Future prospects for the industry.

The search for bibliographic references that supported this study was wide and included academic works from journals in the Engineering area, presentations from technical seminars and congresses, as well as web pages of governmental and institutional parties related to the GHG and steel industry.

Concerning the choice of the steel mills presented in this work, the following criteria were taken into account: (i) aspects of location; (ii) owner group; and (iii) mill capacity in terms of hot metal production. The objective was to select companies that could represent the diversity that exists in the European steel sector.

With regards to the technologies that were discussed here, it was highlighted those that have a more promising degree of technical potential and that contribute more significantly to the reduction of GHG.

\section{Results and discussion}

\subsection{Case study of steel mills in Europe}

In this section, a series of information was gathered from four steel mills in Europe from the following countries: Netherlands, Austria, Germany and France. The study data were consulted through the EU Transaction Log website [10], reports from the Companies and information from the Power Plants linked to the steel companies. The queries on the EU Transaction Log website were made in 2019 and focused on the OHA (Operator Holding Accounts). This dataset consists of data on all installations covered by the EU ETS at the time of download, including the operator, ETS main activity and compliance status such as allocated 
allowances, verified emissions and surrendered allowances. Three types of facilities were considered for the analysis: (i) the steelmaking mill itself, (ii) the own power plants and (iii) third party power plants linked with steel mill. Distant installations such as minimills or other offsite facilities were not considered.

\subsubsection{Dutch steel mill}

The Dutch steel mill is located on the North Sea Coast of Netherlands and mainly produces flat products based on BOF route. The plant comprises of 2 coke batteries, 1 pelletizing plant, 1 sinter plant, 3 blast furnaces, 1 basic oxygen shop, 1 hot strip mill and thin strip caster, cold rolling mill, 3 galvanized lines, 1 pre-finished steel line, hot pickling, annealing and tinning lines. The steel production of this plant in 2018 was 6.9 Mt [11]. In Figures 1 and 2, it is possible to see the emission flowchart of this plant and the comparison between the verified emissions and the free license. Based on total $\mathrm{CO}_{2}$ emissions related to this mill in EU Transaction Log and steel production published, it can be estimated that the specific emission is around $1.80 \mathrm{tCO}_{2} / \mathrm{t}$ steel.

It is noted that half of the emissions produced at the Dutch plant are burnt to heat the furnaces within the steelmaking site, while the other half is sent to two thirdparty power plants. The blast furnace gas that is sent to these third-party plants creates practically the same amount of energy that is consumed in the steel operation. Another interesting point is that the isolated emission from the steel plant is less than the emission license. However, when added to the power plants emissions that should be considered in the whole balance of the steel operation license, the situation changes and there is a deficit in the carbon allowances.

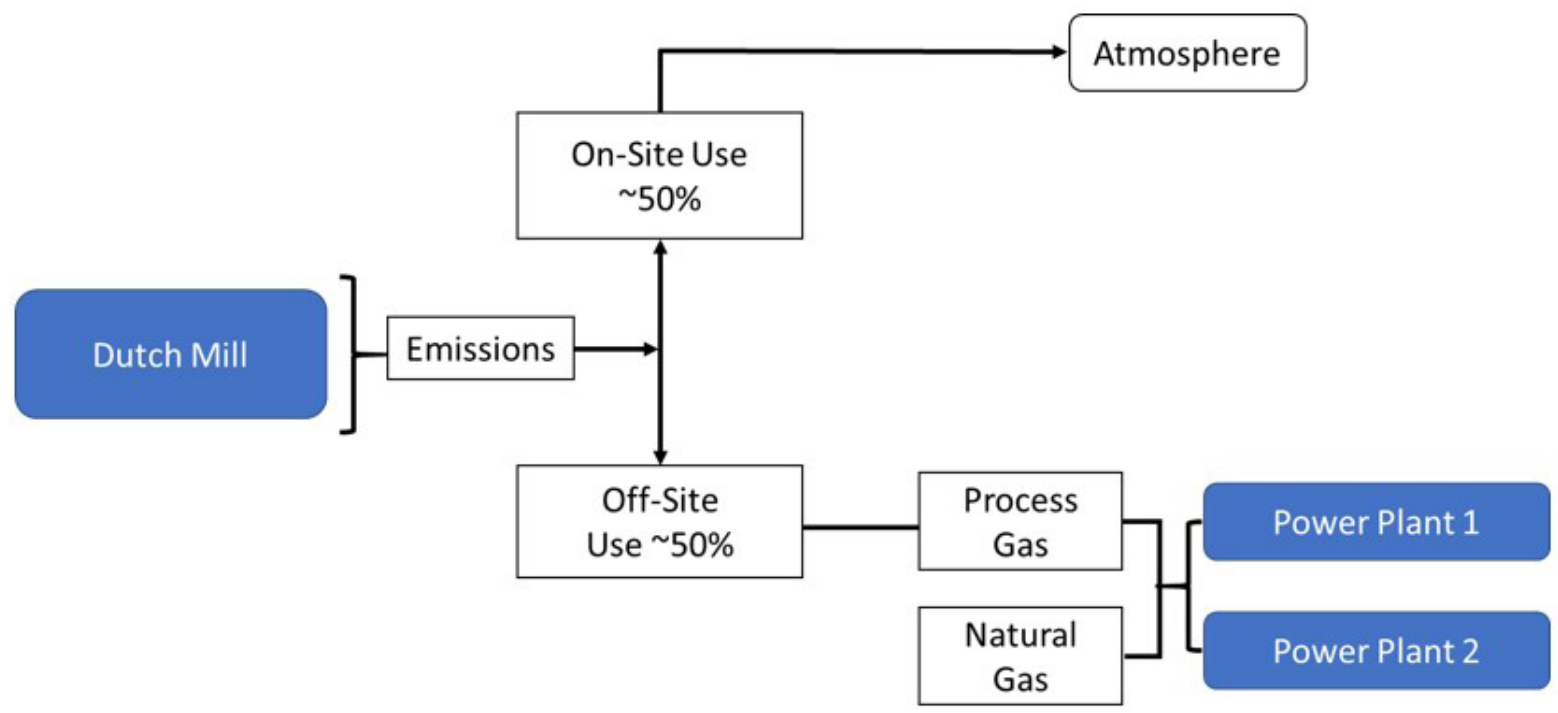

Figure 1. Emission distribution flow in the chain associated with the Dutch steelmaker.

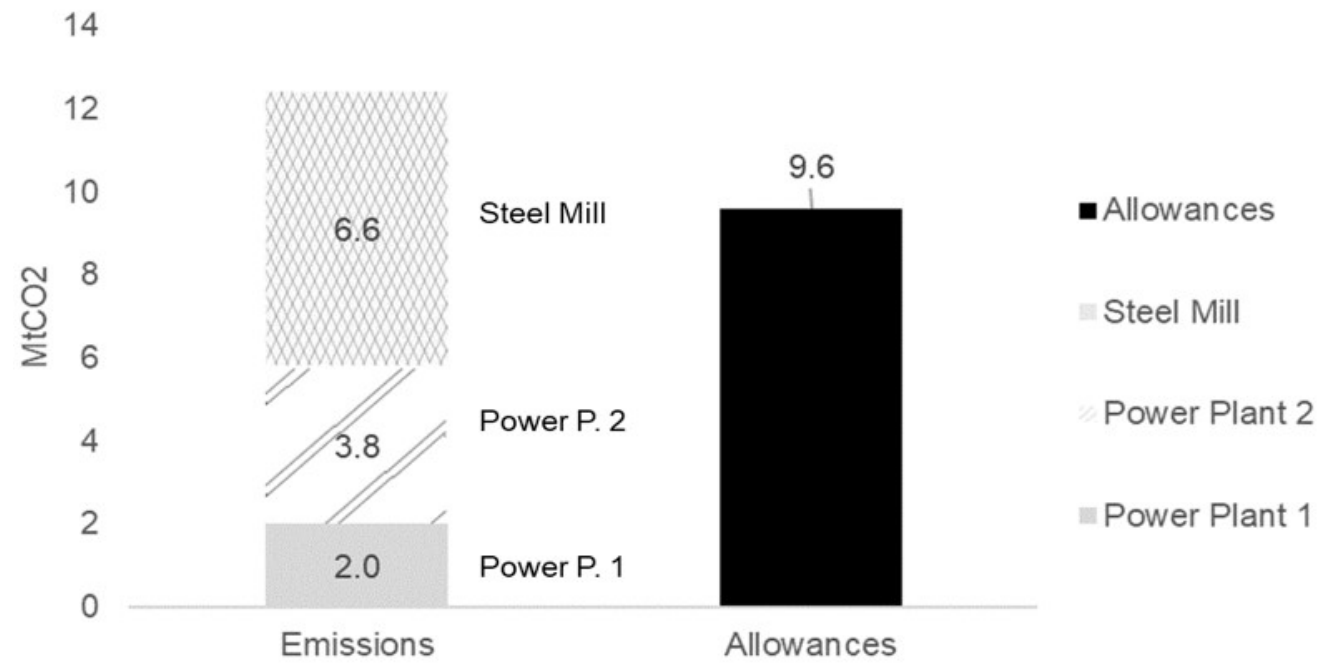

Figure 2. Balance between verified emissions and licenses for the Dutch steelmaker. 


\subsubsection{Austrian steel mill}

This is an integrated steel plant located in the northern part of Austria, ate the Danube river. The plant has 3 blast furnaces which produce steel used for flat products for the energy sector and mechanical engineering applications. Its main products are heavy plate, hot-rolled strip, cold-rolled strip, hot-dip galvanized steel strip, electrogalvanized steel strip and organic-coated steel strip.

In 2018, this mill reported 4.62 Mt of steel production [12]. Comparing this number with the total emissions in the mill showed in Figure 3 it can be stated that each ton of steel produced in generated the equivalent of $1.69 \mathrm{tCO}_{2}$.

The Austrian power plant is integrated with the steel plant. Since 2013, this company started to report data from the power plant implicitly within the steelmaker's data, so there is no way to track the numbers separately.

However, it is known that $80 \%$ of the steelmaker's energy demand is provided by this plant, the remaining is purchased on the market. It is noted that the emissions from this plant also exceed the licenses granted to the company.

\subsubsection{German steel mill}

This mill is located at the Ruhr Valley in Germany. Its products mix includes HRC, CRC, hot dipped/electrogalvanized coil, tinplate, color coated coil, electrical steel and heavy plate. Four blast furnaces operate in this site, which produced $9.8 \mathrm{Mt}$ of pig iron in 2018. The steel production reached $10.4 \mathrm{Mt}$ [13] and the $\mathrm{CO}_{2}$ intensity were about $1.79 \mathrm{tCO}_{2} / \mathrm{t}$ steel, considering the $\mathrm{CO}_{2}$ emitted value in Figure 4. Figure 5 show the plant's emissions diagram as well.

The power plant in the context is owned by the same owners as the steelmaker, but the plant is not integrated into the site as in the Austrian case. The power plant is supplied with a combination of gases where $87 \%$ comes from the top gas in the blast furnaces, $9 \%$ is $\mathrm{CO}$ from the coke plants and $4 \%$ comes from external natural gas. The energy generated

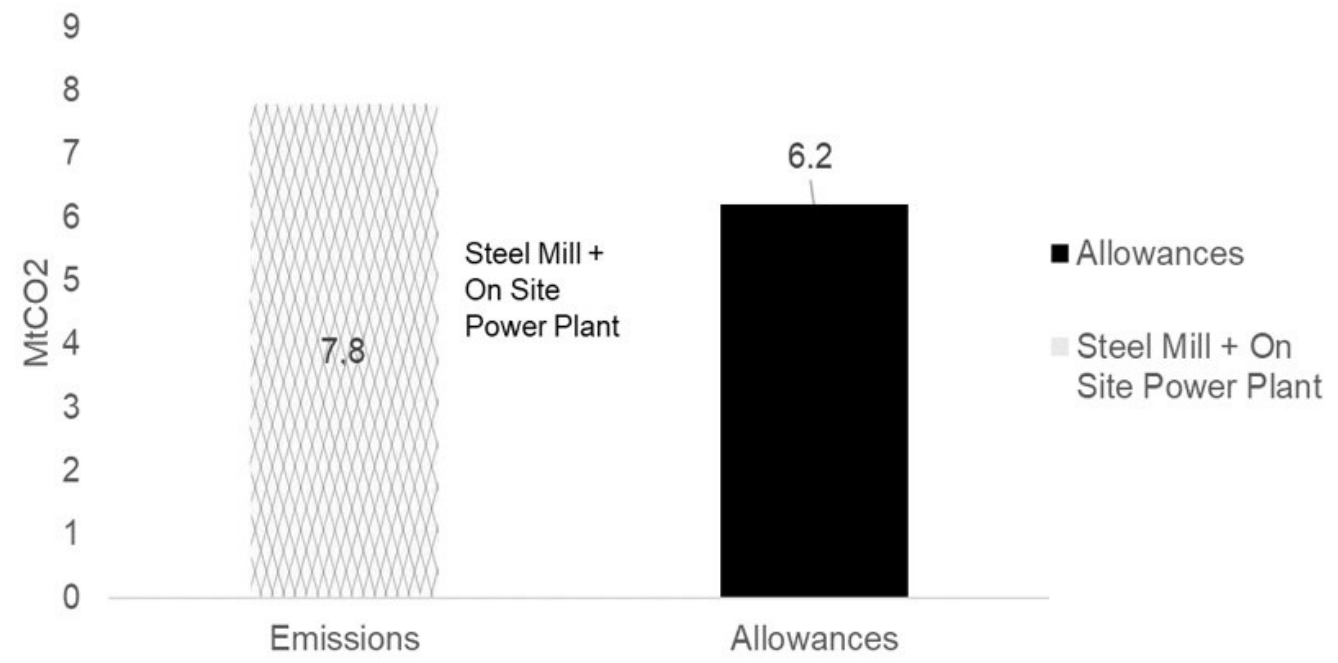

Figure 3. Balance between verified emissions and licenses for the Austrian steelmaker.

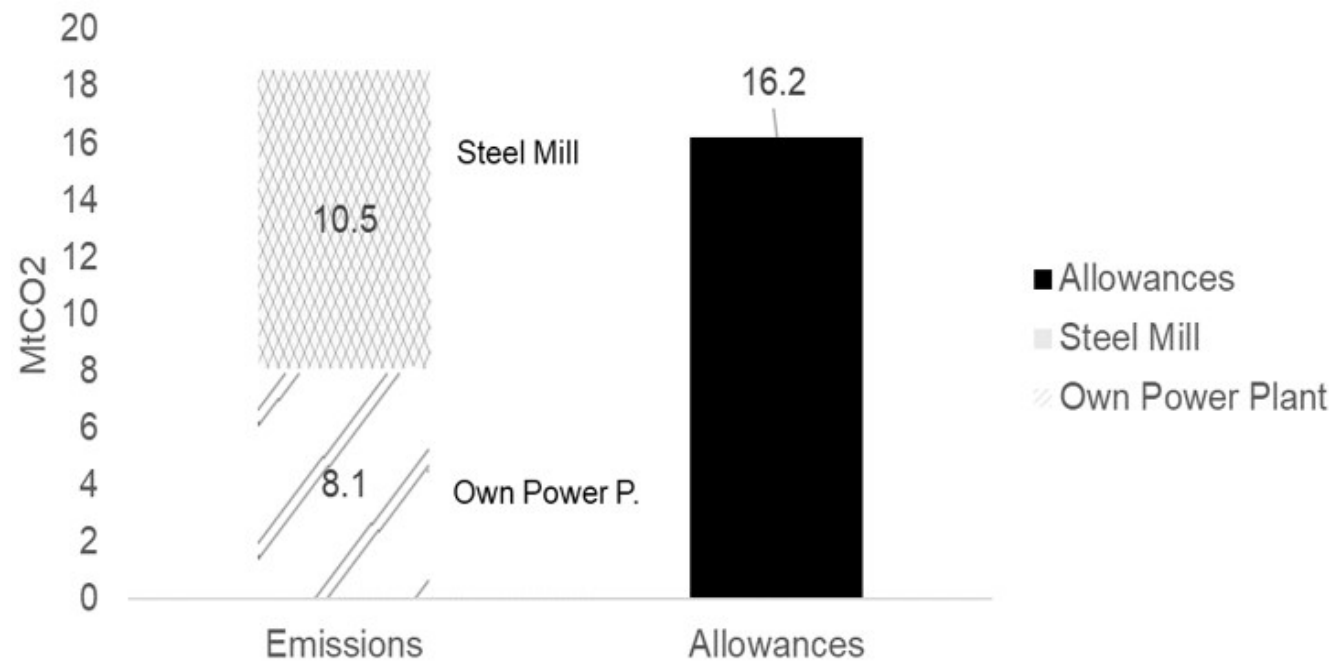

Figure 4. Balance between verified emissions and licenses for the German steelmaker. 


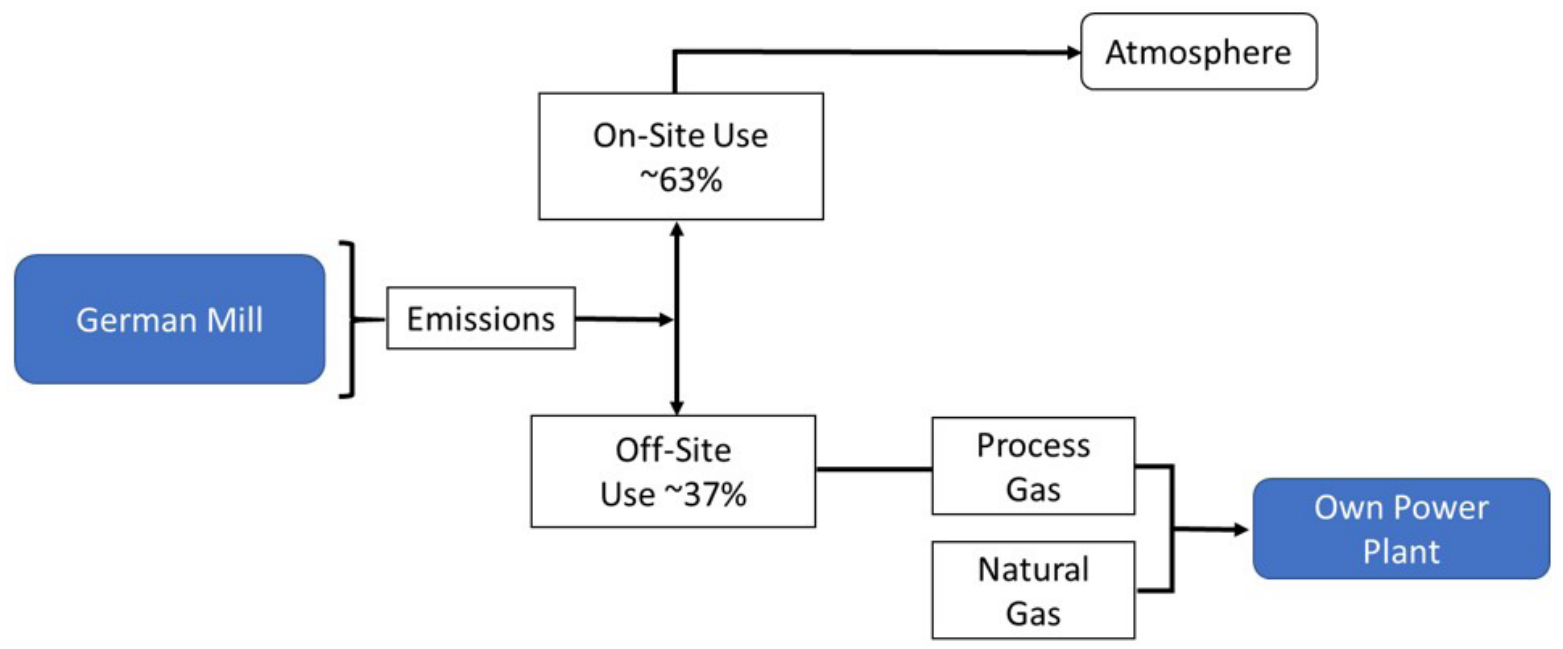

Figure 5. Emission distribution flow in the chain associated with the German steelmaker.

at the power plant is preferably sent to supply the steel mill, but there is flexibility to feed the municipal domestic network. In this scenario, it can be seen that steel mill emission only is lower than the free allocation, but when adding the value of the emissions from the power plant the balance turns to shortage.

\subsubsection{French steel mill}

The French mill belongs to a big multinational steelmaking group. The plant has three blast furnaces and one basic oxygen shop. The company produces both semifinished and finished products in the form of slabs and HRC. The main niche of customers of the plant is the automobile sector. The steel production of this unit was $6.8 \mathrm{Mt}$ in 2018, with a consequent specific emission level of $1.85 \mathrm{tCO}_{2} / \mathrm{t}$ steel [14]. Figures 6 and 7 show information regarding the emissions flow and the balance of emissions with licenses.

Approximately two-thirds of the process gases generated from the steel mill's reactors are emitted to the atmosphere, after the usage in heating purposes and flue gases on site. On the other hand, one-third is destined for a third power plant connected to the plant. This power plant is adapted to operate with both process gas and direct supply of natural gas. The role of the electric power is to supply exclusively the operations of the steel plant and according to the data from the EU Transactions Log, the emission of the plant is $4.5 \mathrm{MtCO}_{2}$. Therefore, the total number of emissions related to the steelmaker's operation totals $12.6 \mathrm{MtCO}_{2}$ and is the largest deficit among the plants presented.

In Figure 8, it is possible to observe an overview of the four plants studied, where it is noted that the Austrian plant is the one that has the smallest deficit between licenses granted and emissions accounted for, besides it is also the plant with the lowest ratio of $\mathrm{CO}_{2}$ emissions for each ton of steel produced. One of the reasons that explains the good specific emission ratio is the low coke rate of its blast furnaces, which can be explained by the use of pre-metallized burden (HBI).
On the other hand, the situation of the Dutch plant and the German plant is quite similar. Both have the $\mathrm{CO}_{2}$ intensity about to 1.8 and the emission deficit are very close. Finally, the French mill is the one with a slightly higher emission per ton of steel and also has a larger total deficit, probably due to low energy efficiency.

The negative balance between emission and licenses of these four plants is an indicator of shortage, but does not necessarily imply that these steelmakers are paying penalties, since there may be mitigating alternatives:

- Savings: credits not used in previous years could have been applied in 2018 instead of paying;

- Traded: allowances through the course of the year;

- Transferred: free allowances from other plants owned by them and used to compensate for these specific mills.

\subsection{Future trends for the steelmaking industry}

Taking global aspect of the need to reduce greenhouse gases and the contribution made by industrial activity, especially in the steel chain, there is a clear need to seek technological alternatives for the primary iron routes. Most of the ongoing efforts can be divided into three different groups [15]:

- CDA(Carbon Direct Avoidance): directly avoids $\mathrm{CO}_{2}$ emissions, either through an increase in the use of renewable energy in the manufacture of steelmaking or replacing carbon in reduction processes;

- $\mathrm{CCU}$ (Carbon Capture and Usage): it consists of capturing $\mathrm{CO}_{2}$ from the industrial process and reusing it as a raw material for chemical conversion or other usages;

- CCS (Carbon Capture and Storage): it is based on the generation of a clean and concentrated $\mathrm{CO}_{2}$ gas that can be transported and then stored. 


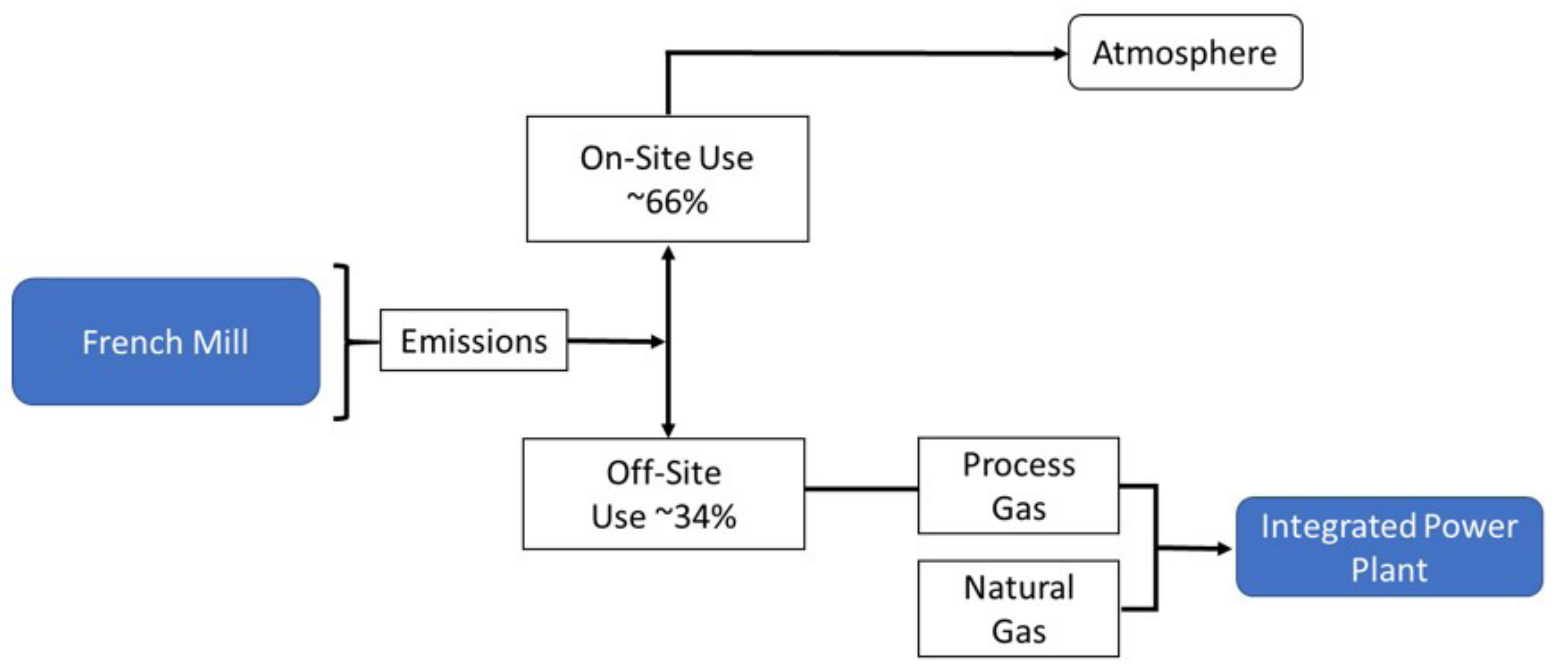

Figure 6. Emission distribution flow in the chain associated with the French steelmaker.

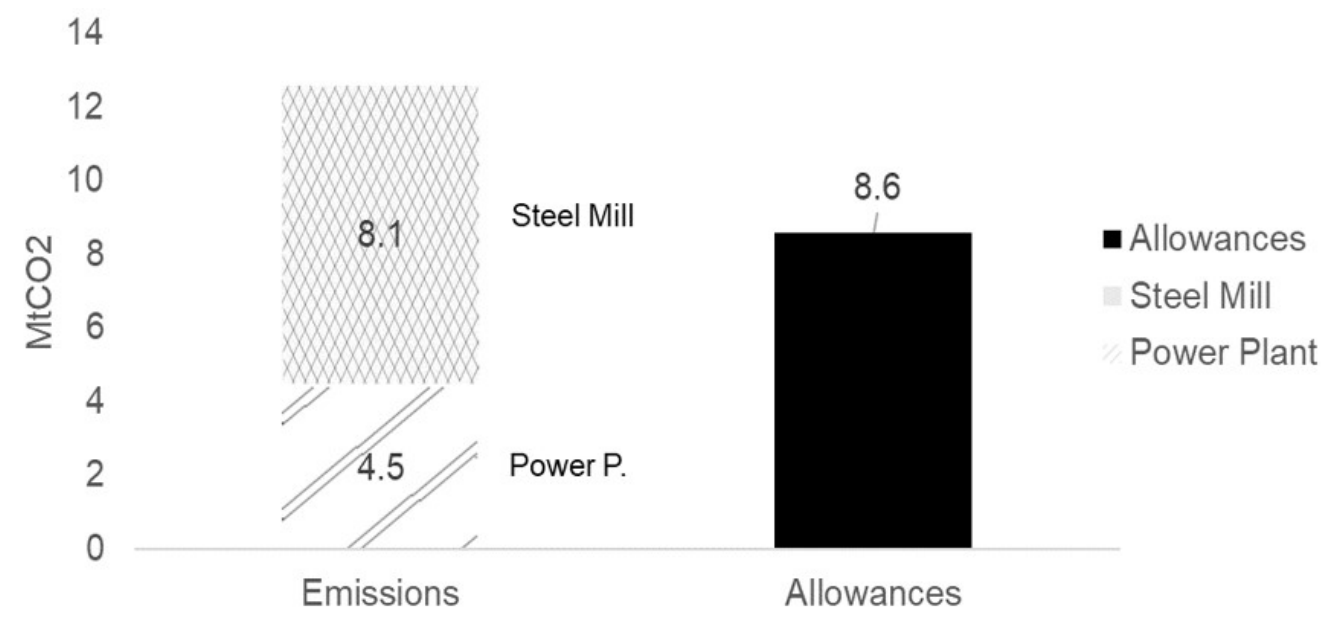

Figure 7. Balance between verified emissions and licenses for the French steelmaker.

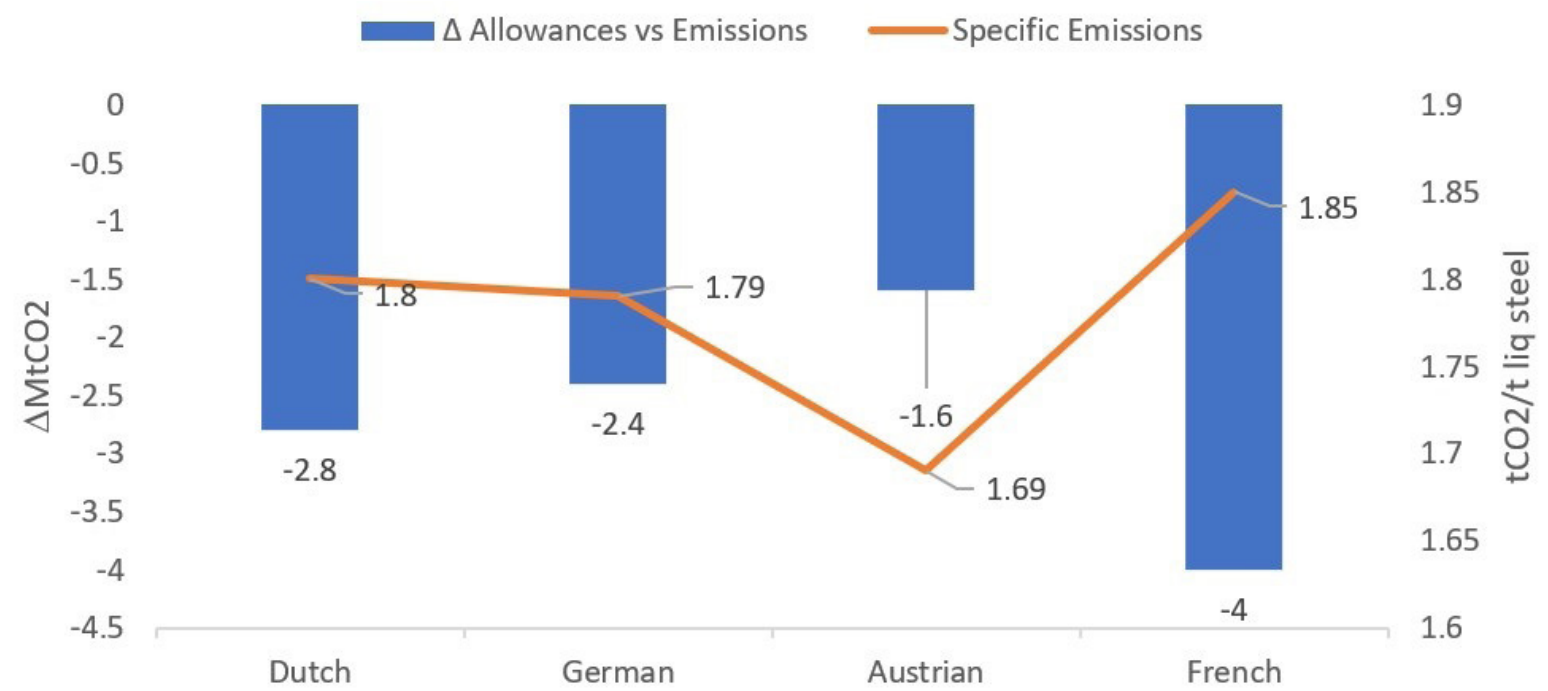

Figure 8. Comparison of the balance of emissions and emission efficiency per ton of steel produced. 
In this context, it can be said that CCU and CCS are palliative resources and due to it they normally do not tend to generate a significant influence to solve the environmental problem. On the other hand, CDA related initiatives are naturally more disruptive and have a such greater potential impact. Among the various CDA initiatives currently being studied for the steel industry, some are highlighted:

- Routes alternatives to obtain primary iron (e.g. greater use of the DR/EAF and electrolysis);

- Use of metallic or pre-metallic in the existing routes;

- Use of less polluting fuels (e.g. biomass);

- Use of cold agglomerates as burden;

- Use of electrolysis process;

- Greater use of hydrogen as a reducing agent in processes.

According to the WSA (2018), the BF/BOF route usually emits approximately 1.85 tons of $\mathrm{CO}_{2}$ per ton of steel produced, whereas 1 ton of steel via the DR-EAF route is responsible for 0.81 tons of $\mathrm{CO}_{2}$ [6]. Factors such as the chemical quality of raw materials loaded in the furnace and the scrap proportion play an important role on the numbers commented by the WSA. However, when comparing the two main technically and economically feasible routes for obtaining steel in the world, it is observed that there is already an important difference on the emissions related to routes. Basically, the direct reduction route has a considerable use of hydrogen that transforms into water steam and then is reformed with natural gas. However, what still limits the expansion of the use of the DR route in many places, remains the low availability of low-cost natural gas [16]. Middle East and North Africa are historical regions with abundant natural gas reserves, but more recently other countries as US have increased its production of sponge iron due to the exploitation of new reserves [17].

Some companies already have plans to partially or gradually replace their current routes to direct reduction and electric furnace routes. Salzgitter, for example, has the SALCOS $®$ project (Salzgitter Low $\mathrm{CO}_{2}$ Steelmaking) which aims to produce steel with a flexible and increasing use of $\mathrm{H}_{2}$ [18]. To achieve this goal, they signed a partnership with Tenova to install the ENERGIRON-ZR reactor combined with a $\mathrm{CO}_{2}$ capture equipment. The expected result is that with this route replacing the blast furnace there will be a $95 \%$ reduction in $\mathrm{CO}_{2}$ emissions [19].

In that circumstances of higher usage of DR route, the HYBRIT project (Hydrogen Breakthrough Ironmaking Technology) led by three Swedish companies, LKAB (supplier of ore and pellets), SSAB (steel mill) and Vattenfall (energy utilities) stands out. This project started in 2016 and more recently in 2018 the proof of concept was completed [20]. The goal is to drastically reduce $\mathrm{CO}_{2}$ emissions from ironmaking, eliminating the need of fossil fuel to reduce ore.

The engineering of this technology initially consists of electrolysis cells that produce $\mathrm{H}_{2}$ and $\mathrm{O}_{2}$ from water.
Then the $\mathrm{H}_{2}$ is stored and before entering the DR reactor, it passes through a condenser. Inside the shaft it promotes the reduction of the iron oxides present in the burden and at the upside section the top gases are collected and redirected to the condenser circuit, where the water vapor is collected and again submitted to the electrolysis cells. Although many of the components of HYBRIT are already well-known, there are still some challenges such as process integration, product quality (raw material needs), $\mathrm{H}_{2}$ production and storage technology, steel mill integration with power station supported by renewable sources and low percentage of carbon (cementite) in sponge iron, which impacts electric consumption in EAF [21]. From an economic point of view, it is estimated that the cost of the steel produced in HYBRIT will be 20 to $30 \%$ larger than steel produced on a conventional route. The feasibility of this new route is highly dependent on the green hydrogen production capacity and its associated costs in the future.

Another interesting development, even more disruptive, because it is a completely new reduction technology, is the project carried out between partners in Austria (VoestAlpine, University, K1-Met) called SuSteel (Sustainable Steel). The reactor consists of a conical reactor with refractory lining and a cylindrical upper part with a water-cooling system. While fines from ores and additives are loaded through the hollow electrode, argon or nitrogen are used as plasma gas and hydrogen as a reducing agent. Thus, the fed material is pushed directly into the plasma arc zone, where reduction and melting occur very quickly. The gas flow takes care of transporting the materials through the tubes and a mass spectrometer measures the composition of the gas during the test. The process works in a batch model and at the end of the operation, the liquid iron solidifies in the reactor and after decoupling the electrode, the solid metal solution is discharged by a crane [12].

Since most of these projects and initiatives for the development of new routes and/or intensive use of hydrogen in Europe are medium and long term, there are other actions that are being evaluated for the short term [22]. Such actions include the injection of $\mathrm{H}_{2}$ into conventional blast furnaces.

The rates that have been tested are low due to operational restrictions and caution that must be taken, for example with the thermal balance. However, the environmental impact is already well known. A recent study [23] showed that under regular operating conditions a hydrogen injection of 27.5 $\mathrm{kg} / \mathrm{t}$ hot metal can reduce relative emissions by $21.4 \%$ when compared to a typical operation using pulverized coal at a rate of $120 \mathrm{~kg} / \mathrm{t}$ hot metal.

Finally, the promising higher use of hydrogen in the steelmaking chain leads to a major challenge to generate $\mathrm{H}_{2}$ with technical, environmental and economic sustainability, and competitiveness. The most common route to obtain hydrogen today is through gas reform reactions that originally consume natural gas as the main input $[24,25]$. Other cleaner ways, such as using biomass combined with $\mathrm{CO}_{2}$ capture and, as a state of the art, using water electrolysis with related renewable energy source, are the target of many projects, but persist with the production cost as main obstacle [26]. 


\section{Conclusions}

In view of the study presented, it can be concluded that:

- The demand for greener products and more sustainable processes in the steelmaking industry will be increasing. In Europe, a region where the ETS is well established, the impact of these policies on the steel industry is notable. Four plants from different countries faced a deficit between the allowances and the verified emissions. In addition, it is also interesting to note that the efficiency of emissions per ton of steel produced varied in minor quantities from one plant to another;

- Among the existing approaches to prevent GHG emissions, the CDA causes the most positive impact and, therefore, it has guided several projects of new technological routes. Most of the new low-carbon technological routes go through intensive use of hydrogen as a reducing agent. Existing projects at different maturity degrees, ranging from the migration from conventional $\mathrm{BF} / \mathrm{BOF}$ route to DR routes, to new equipment and routes and the use of hydrogen in conventional blast furnaces;
- Hydrogen production is a critical factor both for calculating the carbon footprint and for the associated costs. Electrolyzers powered by wind, solar or nuclear generators would be the most environmentally friendly paths;

- Fossil-free steel will certainly be more expensive than current steel production. Assessing market segments that are willing to pay a premium for green steel products is an important point for discussing projects;

- Studies on sustainable steel production alternatives need to be further explored and disseminated. In a global and ubiquitous industry such as steelmaking, those who focus efforts in this line and succeed, will certainly acquire competitive advantages that may be decisive in the future.

\section{Acknowledgment}

The authors would like to thank CAPES-PROEX, CNPq and FAPEMIG for stimulating and supporting research

\section{References}

1 Mathiesen L, Maestad O. Climate policy and the steel industry: achieving global emission reductions by an incomplete climate agreement. Energy Journal. 2004;25(4):91-114.

2 United Nations. Climate change: the Paris agreement. 2017 [acesso em 20 maio 2020]. Disponível em: https:// unfccc.int/process-and-meetings/the-paris-agreement/the-paris-agreement

3 Wadhwa D, Mani MS, Hussein Z, Gopalakrishnan BN. Paris climate agreement and the global economy: winners and losers. The World Bank; 2018.

4 Change OC. World Meteorological Organization. Intergovernmental Panel on Climate Change; 2007.

5 European Commission. EU ETS handbook. Brussels; 2015 [acesso em 20 maio 2020]. Disponível em: https:// ec.europa.eu/clima/sites/clima/files/docs/ets_handbook_en. pdf

6 World Steel Association. Steel's contribution to a low carbon future and climate resilient societies. 2018 [acesso em 20 maio 2020]. Disponível em: https://www.worldsteel.org/en/dam/jcr:7ec64bc1-c51c-439b-84b8-94496686b8c6/ Position_paper_climate_2020_vfinal.pdf

7 International Carbon Action Partnership. Emissions trading worldwide: status report 2018. Berlin: ICAP; 2018.

8 International Carbon Action Partnership. ETS map. 2019 [acesso em 20 maio 2020]. Disponível em: https:// icapcarbonaction.com/en/ets-map?etsid=79

9 Borghesi S, Montini M, Barreca A. The EU ETS: the pioneer - main purpose, structure and features. In: Borghesi S, Montini M, Barreca A, editors. The European emission trading system and its followers. Cham: Springer; 2016. p. 1-28.

10 European Commission. Emission Trading System (EU ETS). EU community independent transaction log. Climate change, environment. 2018.

11 Tata Steel. Sustainability report 2018/2019. 2019 [acesso em 20 maio 2020]. Disponível em: https://www.sabprofiel. com/assets/user/Documentatie/Tata\%20Steel\%20Sustainability\%20Report\%20FY18-19_English.pdf

12 Voestalpine. Enviromental statement. 2019 [acesso em 20 maio 2020]. Disponível em: https://www.voestalpine.com/ group/static/sites/group/.downloads/en/group/2019-environmental-statement.pdf

13 Thyssenkrupp. Annual report 2018/2019. 2019 [acesso em 20 maio 2020]. Disponível em: https://ucpcdn. thyssenkrupp.com/_legacy/UCPthyssenkruppAG/assets.files/media/investoren/berichterstattung-publikationen/ update-21.11.2019/en/thyssenkrupp-gb-2018-2019-en-web_neu.pdf 
The impact of the emission trading scheme on the european steel industry and the future trends for technologies for obtaining primary iron

14 ArcelorMittal. Fact Book 2018. 2019 [acesso em 20 maio 2020]. Disponível em: https://factbook2018.arcelormittal. com/ /media/Files/A/Arcelormittal-Factbook-2018/AM_FactBook_2018.pdf

15 Sormann A, Seftejani MN, Schenk J, Spreitzer D. Hydrogen: the way to a carbon free steelmaking. In: AdMet; 2018; Lviv, Ukraine. Austria: voestalpine Stahl Linz GmbH; 2018.

16 Smil V. Still the iron age: iron and steel in the modern world. Amsterdam: Butterworth-Heinemann; 2016.

17 Arens M, Worrell E, Eichhammer W, Hasanbeigi A, Zhang Q. Pathways to a low-carbon iron and steel industry in the medium-term- the case of Germany. Journal of Cleaner Production. 2017;163:84-98.

18 Hille V, Redenius A. SALCOS-schrittweise, flexible Dekarbonisierung auf basis bewährter Technologie. Stahl und Eisen. 2018;138(11):95-101.

19 Dorndorf M, Duarte P, Argenta P, Maggiolino S, Marcozzi M. Transforming the steelmaking process. Steel Times International. 2018;42(7):29-32.

20 HYBRIT. Summary of findings from HYBRIT pre-feasibility study 2016-2017. 2018 [acesso em 20 maio 2020]. Disponível em: https://ssabwebsitecdn.azureedge.net/-/media/hybrit/files/hybrit_brochure.pdf

21 Åhman M, Olsson O, Vogl V, Nyqvist B, Maltais A, Nilsson LJ, et al. Hydrogen steelmaking for a low-carbon economy. Stockholm: Stockholm Environment Centre and Lund University, 2018.

22 Warner NA. Zero $\mathrm{CO}_{2}$ steelmaking in a future low carbon economy. 1. Energy conservation in smelting hematite ore directly to refined iron slab. Mineral Processing and Extractive Metallurgy. 2018;127(2):73-83.

23 Yilmaz C, Wendelstorf J, Turek T. Modeling and simulation of hydrogen injection into a blast furnace to reduce carbon dioxide emissions. Journal of Cleaner Production. 2017;154:488-501.

24 Tacke KH, Steffen R. Hydrogen as a reductant for iron ores and the effects on $\mathrm{CO}_{2}$ formation. In: Proceedings of International Symposium on Global Environment and Steel Industry (ISES'03); 2003; Beijing, China. Beijing: Chinese Society for Metals; 2003.

25 Mosca L, Medrano Jimenez JA, Wassie SA, Gallucci F, Palo E, Colozzi M, et al. Process design for green hydrogen production. International Journal of Hydrogen Energy. 2020;45(12):7266-7277.

26 Noldin J. Decarbonization and green eletricity in the steel industry. ABM Magazine. 2020 [acesso em 16 June 2020];76:22-32. Disponível em: https://revistaabmdigital.com.br/edicoes/655/\#p=22

Received: 1 July 2020

Accepted: 16 Mar. 2021 